\title{
Evaluation of Workers' Exposure to Dust, Ammonia and Endotoxin in Poultry Industries at the Province of Isfahan, Iran
}

\author{
Farideh GOLBABAEI* and Firouzeh ISLAMI
}

\begin{abstract}
Department of Occupational Health, School of Public Health and Institute of Public Health Research, Tehran University of Medical Sciences, P.O. Box 6446 TEHRAN 14155, I. R. Iran
\end{abstract}

Received February 1, 1999 and accepted November 15, 1999

\begin{abstract}
This study was conducted to assess various environmental exposure measurements (total dust, ammonia and endotoxin) of poultry workers at the province of Isfahan, Iran. The results show that the workers who worked in enclosed systems of parent stock barns have the highest exposure to total and respirable dust: $21.3 \pm 3.2$ and $4.6 \pm 0.9 \mathrm{mg} / \mathrm{m}^{3}$, respectively. In comparison with different ages of chicken, the highest concentration of total and respirable dust were $5.4 \pm 0.7$ and $3.3 \pm 0.7$ $\mathrm{mg} / \mathrm{m}^{3}$ in the 45 th day. In the above mentioned situation, the results of endotoxin concentrations were 20.6 \pm 1.1, 23.6 $\pm 2.2,21.3 \pm 1.2$ and $26.8 \pm 1.8 \mathrm{ng} / \mathrm{m}^{3}$, respectively. Ammonia concentrations had the highest rate in enclosed systems of laying hens in winter and the 45th day of chicken age, measuring $33.2 \pm 5.2$ and $20.2 \pm 3.0 \mathrm{mg} / \mathrm{m}^{3}$, respectively.
\end{abstract}

Key words: Parent stock, Broiler, Chicken, Laying hen, Total dust, Respirable dust, Ammonia, Endotoxin

\section{Introduction}

Prior to 1954 , poultry processing in Iran followed a traditional procedure and was mainly done in small scales at home. In that year, by importing improved species of chicken the foundations for the poultry industry based on modern methods and techniques were laid. Considerable growth in poultry processing industries was possible because of veterinary preventive medicine techniques and improvement in breeding, feed conversion, housing and marketing practices ${ }^{1}$.

The population growth in Iran and the background of food requirements, especially livestock and poultry products have contributed to the development of this essential industry.

Today the poultry processing industry plays a major role in the Iranian economy. During the past 30 years, a considerable number of private and state firms have been

\footnotetext{
*To whom correspondence should be addressed.
}

established. In various processes of production and breeding of poultries, aerosols, bioaerosols and gases are produced, therefore the operators in the industry are exposed to the above pollutants, thus their health are under threat.

This study was part of an environmental and crosssectional epidemiological investigation of pulmonary functions in the poultry industries in the province of Isfahan. Epidemiological results are being processed and will be presented in a separate paper. The goals of this part of the project were to characterize human exposure to total and respirable dust, ammonia and endotoxin in poultries of Isfahan province, Iran, which are responsible for the production of more than 16 percent of poultry production capacity in the country during summer and winter.

\section{Materials and Methods}

This research was conducted in 13 poultry barns including parent stock barns, broiler barns and laying hen barns in 
Table 1. Means and standard deviations of poultry workers' exposure to total and respirable dust $\left(\mathrm{mg} / \mathrm{m}^{3}\right)$

\begin{tabular}{|c|c|c|c|c|c|c|c|}
\hline \multirow{3}{*}{\multicolumn{2}{|c|}{ Type of Poultry }} & \multicolumn{4}{|c|}{ Summer } & \multirow{2}{*}{\multicolumn{2}{|c|}{$\frac{\text { Winter }}{\text { Enclosed system }}$}} \\
\hline & & \multicolumn{2}{|c|}{ Open system } & \multicolumn{2}{|c|}{ Enclosed system } & & \\
\hline & & Total dust & Respirable dust & Total dust & Respirable dust & Total dust & Respirable dust \\
\hline Parent s & & $7.1 \pm 1.6$ & $2.3 \pm 0.9$ & $19.7 \pm 5.2$ & $2.4 \pm 0.8$ & $21.3 \pm 3.2$ & $4.6 \pm 0.9$ \\
\hline Broiler & & $4.2 \pm 0.5$ & $1.6 \pm 0.2$ & & & $3.7 \pm 0.4$ & $2.2 \pm 0.2$ \\
\hline Laying 1 & & $10.5 \pm 1.7$ & $1.7 \pm 0.8$ & $15.0 \pm 3.6$ & $2.3 \pm 0.8$ & $15.8 \pm 1.4$ & $2.5 \pm 0.6$ \\
\hline Control & With litter & - & - & - & - & $3.1 \pm 0.8$ & $1.4 \pm 0.2$ \\
\hline & Without litter & - & - & - & - & $1.1 \pm 0.2$ & $0.5 \pm 0.1$ \\
\hline
\end{tabular}

summer and winter in the province of Isfahan, Iran. This study has been carried out in 3 stages as follows:

\section{Exposure to dust}

Workers' exposure to total and respirable dust was measured using the ACGIH method ${ }^{2}$. In order to determine the total dust concentration, samples were collected using Teflon filters with $37 \mathrm{~mm}$ diameter and $1 \mu \mathrm{m}$ pore size and 3 piece cassette holder connected to a personal sampling pump (SKC, Model 224-PXR3) operating at a flow rate of $1.5 \mathrm{l} / \mathrm{min}$. Teflon filters were used because of their durability and flexibility for endotoxin analysis in addition to meeting the NIOSH 0500 requirement for hydrophobic equivalency to PVC filter ${ }^{3}$. Respirable dust samples were collected using a $10 \mathrm{~mm}$ Dorr-olive cyclone on series with $37 \mathrm{~mm}$ Teflon filters connected to a personal pump (SKC, Model 224 PXR3) operating at a flow rate of $1.7 \mathrm{l} / \mathrm{min}$. The mass of dust in all samples were determined gravimetrically.

\section{Exposure to ammonia}

Determination of ammonia concentration was done by a combination of the NIOSH method P \& CAM 205 and $\mathrm{crook}^{4}$. Equipment for ammonia vapor sampling consisted of a personal sampling pump (SKC, Model 222-3) and a midget impinger. The absorbing solution was sulfuric acid, $0.1 \mathrm{M}$. Sampling was done at a flow rate of $200 \mathrm{ml} / \mathrm{min}$. All samples were analyzed using the Nessler indicator, according to the NIOSH recommendations ${ }^{5}$.

\section{Exposure to endotoxin}

Following gravimetric analysis (total and respirable dust collected in the first phase), dust samples were extracted with $10 \mathrm{ml}$ sterile, pyrogen-free water by shaking by a rotator (ARTHOR H. THOMAS CO., USA) for an hour before they are placed in centrifuge (KUBOTA CO., Japan) for 10 minutes in order to complete the deposition of dust. All of these stages were done in an ice-container, since the temperature of the endotoxin solution must be kept at 2$8^{\circ} \mathrm{C}$. The samples were then analyzed for endotoxin content using a modified endpoint QCL-1000 Quantitative Chromogenic LAL (Limulus Amoebocyte Lysate) known as toxicolor system (Seikagok corpo-catain Co.). The endotoxin concentrations were assayed along with a set of endotoxin standards. Absorbance at $405 \mathrm{~nm}$ was determined using a Nova spectrophotometer and the endotoxin concentration in the air was then calculated.

\section{Results}

This research was carried out in 6 barns of broiler, 4 barns of parent stock and 3 barns of laying hen in Isfahan. The workers were all male and their average ages were $35.5 \pm$ 8.5, 40.2 \pm 10.9 and $42.1 \pm 9.5$ years in the mentioned areas, respectively. The average of their work history was $8.0 \pm$ $5.4,10.9 \pm 7.6$ and $17.5 \pm 6.3$ years, respectively.

In poultry processing industries, dust is emitted into the air because of shedding feathers barbules, refuse and food. Thus the workers are constantly exposed to it. The amount of workers exposure to total and respirable dust was determined separately in summer and winter months, and in both open and enclosed systems as shown in Table 1. According to the findings, the workers who worked in enclosed system of parent stock barns in winter time, had the highest exposure, $21.3 \pm 3.2 \mathrm{mg} / \mathrm{m}^{3}$, and the maximum concentration of respirable dust exposure was $4.6 \pm 0.86$ $\mathrm{mg} / \mathrm{m}^{3}$. Overall differences between seasons and barn systems were confirmed by statistical analysis of variance for all agents $(\mathrm{p}<0.05)$.

Total dust concentrations in parent stock and laying hen barns in enclosed system conditions, both in summer and winter, exceeded the American Conference of Governmental Industrial Hygienists (ACGIH) threshold limit value (TLV) 
Table 2. Means and standard deviations of total \& respirable dust $\left(\mathrm{mg} / \mathrm{m}^{3}\right)$ exposure against different ages of chicken growth

\begin{tabular}{cccccc}
\hline \multirow{2}{*}{$\begin{array}{c}\text { Age of growth } \\
\text { (day) }\end{array}$} & \multicolumn{2}{c}{ Open system } & & \multicolumn{2}{c}{ Enclosed system } \\
\cline { 2 - 3 } \cline { 5 - 6 } & Total dust & Respirable dust & & Total dust & Respirable dust \\
\hline 15 & $2.0 \pm 0.3$ & $0.9 \pm 0.2$ & & $2.1 \pm 0.3$ & $1.3 \pm 0.2$ \\
30 & $4.0 \pm 0.9$ & $1.3 \pm 0.2$ & & $3.7 \pm 0.7$ & $1.9 \pm 0.3$ \\
45 & $4.5 \pm 0.7$ & $2.7 \pm 0.5$ & & $5.4 \pm 0.7$ & $3.3 \pm 0.7$ \\
\hline
\end{tabular}

Table 3. Means and standard deviations of poultry workers' exposure to ammonia $\left(\mathbf{m g} / \mathrm{m}^{3}\right)$

\begin{tabular}{|c|c|c|c|c|}
\hline \multirow{2}{*}{\multicolumn{2}{|c|}{ Type of poultry }} & \multicolumn{2}{|c|}{ Summer } & \multirow{2}{*}{$\frac{\text { Winter }}{\text { Enclosed system }}$} \\
\hline & & Open system & Enclosed system & \\
\hline \multicolumn{2}{|c|}{ Parent stock } & $26.6 \pm 3.3$ & $30.4 \pm 4.5$ & $28.8 \pm 12.2$ \\
\hline \multicolumn{2}{|l|}{ Broiler } & $12.3 \pm 1.5$ & - & $13.9 \pm 1.7$ \\
\hline \multicolumn{2}{|c|}{ Laying hen } & $15.8 \pm 1.6$ & $31.2 \pm 5.1$ & $33.2 \pm 5.2$ \\
\hline \multirow[t]{2}{*}{ Control } & With litter & - & - & $6.2 \pm 1.2$ \\
\hline & Without litter & - & - & $2.3 \pm 0.4$ \\
\hline
\end{tabular}

of $10 \mathrm{mg} / \mathrm{m}^{3}$ for nuisance particles. None of the personal respirable dust samples' TWAs exceeded the current permissible exposure limit (PEL) of $5 \mathrm{mg} / \mathrm{m}^{3}$ for respirable nuisance dust. However, almost all personal respirable TWAs exceeded the suggested guideline of $0.23 \mathrm{mg} / \mathrm{m}^{3}$ for respirable livestock dust ${ }^{6}$.

In comparison between different days of age of chicken growth (15th, 30th and 45th days), the highest exposure of the workers to total dust was $5.4 \pm 0.7 \mathrm{mg} / \mathrm{m}^{3}$ and to respirable dust $3.3 \pm 0.7 \mathrm{mg} / \mathrm{m}^{3}$. These results were found in the enclosed system and in the 45th day of growth (Table 2). Such high concentration can be explained due to the same contributing factors mentioned earlier.

One of the other contaminants in poultry processing industries is ammonia which is produced mainly as a result of the refuse. Ammonia concentrations in enclosed laying hen barns in cold season: $33.2 \pm 5.2 \mathrm{mg} / \mathrm{m}^{3}$ (Table 3 ) and in the 45 th day of chicken age: $20.2 \pm 3.0 \mathrm{mg} / \mathrm{m}^{3}$ are more than other conditions (Table 4). Ammonia TWAs exceeded 7 ppm (suggested health guideline for enclosed livestock environments) ${ }^{6}$ ) for all samples except ammonia concentrations during the 15th day of age chicken growth. None of the samples' TWAs exceeded the ACGIH TLV of $25 \mathrm{ppm}^{7)}$ in the chicken barns. In enclosed systems during the winter and the summer, ammonia concentrations in the parent stock and laying hen barns exceeded the TLV for ammonia, however in open systems it is more than the TLV
Table 4. Means and standard deviations of ammonia concentration $\left(\mathrm{mg} / \mathrm{m}^{3}\right)$ against different days of chicken age

\begin{tabular}{ccc}
\hline $\begin{array}{c}\text { Days of } \\
\text { chicken age }\end{array}$ & Open system & Enclosed system \\
\hline 15 & $6.6 \pm 1.4$ & $6.2 \pm 1.3$ \\
30 & $12.3 \pm 2.4$ & $14.5 \pm 2.3$ \\
45 & $17.9 \pm 2.3$ & $20.2 \pm 3.0$ \\
\hline
\end{tabular}

only in parent stock barns.

The results of determination of endotoxin level in total and respirable dust are shown in Table 5. Based on the data given by this table, the maximum endotoxin concentrations in total and respirable dust in the parent stock barns are 20.6 \pm 1.1 and $23.6 \pm 2.2 \mathrm{ng} / \mathrm{m}^{3}$, respectively. The peak of endotoxin concentrations in the chicken barns on the 45th day of chicken age was $21.3 \pm 1.2 \mathrm{ng} / \mathrm{m}^{3}$ for total dust and $26.8 \pm 1.8 \mathrm{ng} / \mathrm{m}^{3}$, for respirable dust (Fig. 1).

All samples' TWAs were greater than $10 \mathrm{ng} / \mathrm{m}^{3}{ }^{8}$. However, the currently discussed occupational health threshold at the workplace is around $5 \mathrm{ng} / \mathrm{m}^{3}\left(50 \mathrm{Eu} / \mathrm{m}^{3}\right)^{9)}$. In chicken barns, the endotoxin concentration in the respirable samples were all greater than the recommended limit, nevertheless, these only apply to 30th and 45th days of chicken growth in the case of total dust. 
Table 5. Means and standard deviations of endotoxin in total and respirable dust $\left(\mathbf{n g} / \mathrm{m}^{3}\right)$

\begin{tabular}{|c|c|c|c|}
\hline Type & of poultry & Total dust & Respirable dust \\
\hline \multicolumn{2}{|c|}{ Parent stock } & $20.6 \pm 1.1$ & $23.6 \pm 2.2$ \\
\hline \multicolumn{2}{|l|}{ Broiler } & $18.7 \pm 1.4$ & $22.2 \pm 1.3$ \\
\hline \multicolumn{2}{|c|}{ Laying hen } & $14.2 \pm 0.9$ & $14.5 \pm 1.3$ \\
\hline \multirow[t]{2}{*}{ Control } & With litter & $13.8 \pm 1.4$ & $13.1 \pm 1.5$ \\
\hline & Without litter & $6.8 \pm 1.2$ & $5.4 \pm 1.0$ \\
\hline
\end{tabular}

\section{Discussion}

The Present research and evaluation of the air pollution have been carried out in poultry processing industries in Isfahan, Iran. Based on the obtained results, the exposures of workers in the parent stock barns to total and respirable dust in winter and in enclosed systems have been the highest as it exceeded the Danish Occupational Limit (OEL) of 3 $\mathrm{mg} / \mathrm{m}^{3}$ for organic dust ${ }^{10)}$ by at least a factor of 6 .

This can be explained in that poulty are sensitive to cold, and with the decrease of temperature, they may become more prone to diseases, therefore, in order to prevent the heat loss in winter, halls have less ventilation. Lack of sufficient ventilation results in a higher concentration of dust in the barn. In addition to this, poultry try to maintain body temperature and prevent heat loss by inflating their feathers. This also results in a concentration of contaminants in the air. Higher concentration in the winter months have been reported in other studies ${ }^{3,11)}$.

In enclosed systems, the ventilation is only through mechanical means, while in open systems both mechanical and natural ventilation methods are used simultaneously for the reduction of pollution level. These differences in the two systems produced a different exposure level of 2.5:1, but no difference in the exposure to respirable dust (1.04:1).

In chicken growing halls, as the chicks grow, their movement and food consumption increase. Therefore the amount of refuse is increased and these factors contribute to increase the dust generation in the 45th day with respect to the 15 th day of age by $1.95: 1$. In addition to these causes, while the chick grows up, its early feather barbules shed and permanent feathers begin to grow. Consequently, in addition to the wood particles, refuse and food, the spread feathers in the air cause the dust pollution to increase. Significant positive correlateion was found between dust concentration and the age of poultry ${ }^{12}$. Total and respirable dust concentrations in control halls with the litter were about 3 times more than control halls without the litter, as the litter

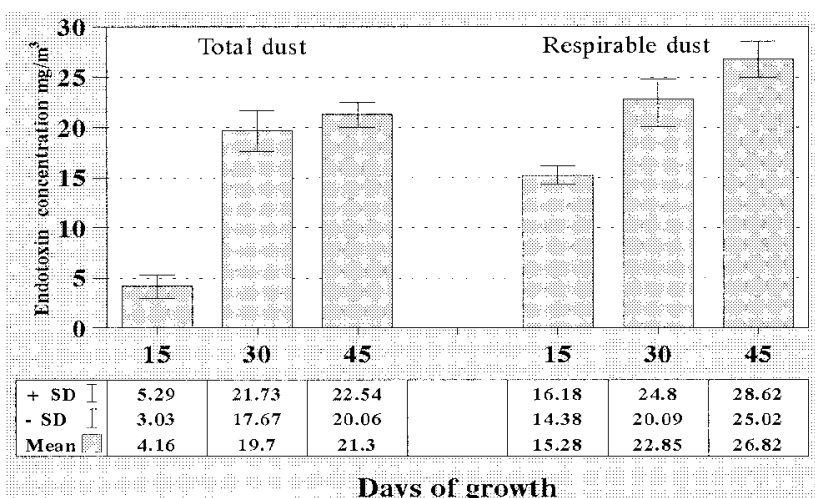

Fig. 1. Endotoxin concentrations in total and respirable dust against different ages of chicken growth.

composed of wood shavings, and the wood particles in addition to other particles deposited on it, were spread by the air current in the hall and were suspended in the air. The duration of using the litter also effects on dust concentration because the new litter is free of refuse, feathers, poultry food and microorganisms. Hence the workers' exposure to dust may lead the chronic cough, chronic phlegm, chronic bronchitis, chest tightness ${ }^{13)}$ and development of acute and chronic respiratory symptoms and lung function changes ${ }^{12-16)}$. Since the major part of the dust is of organic nature, exposure to it may lead to an increased incidence of organic dust toxic syndrome (ODTS) and mucous membrane irritation (MMI). Also observed is a relation between fatigue at work and bronchial reactivity reported in other studies ${ }^{17}$.

Ammonia concentrations in laying hen barns in the cold season is more than of other barns. This is due to the growing conditions of laying hen in the cage system. In this type, the density of population is 4 to 5 times greater than the floor type, causing a considerable accumulation of refuse.

Since ammonia levels generaly rise with the increase in relative humidity and decrease with the indoor air circulation increase ${ }^{18)}$, controlling the relative humidity and air movement especially in litter type barns must be considered. In the cage system, the cages are designed in such a way that refuse goes into a deep duct which is designed under the cages. The refuse is evacuated daily in the warm season and once in a several days in the cold season. This is the reason for increase ammonia concentrations in the winter causing exposed workers to experience symptoms such as burning, watery eyes, sneezing, stuffy, runny nose, cough, burred vision, light sensivity, sore throat, headache and nausea $^{19)}$. 
Endotoxin results show that its concentration in parent stock barns in winter is more than the other barns. Lack of sufficient ventilation in the cold season cause the concentration of endotoxin in the air to rise. The amount of endotoxin in total dust and respirable samples are 2.1 and $2.4 \mathrm{TLV}$, respectively. In other words, endotoxin extracted from respirable dust is approximately 1.2 times more than its amount in total dust samples. This shows that endotoxin largely sticks to the fine particles. According to the obtained results, there are some endotoxin in the air of all studied areas and the most polluted are first parent stock barns and second chicken growth barns. Also the highest endotoxin concentration was identified during the 45th day of chicken age. Thus workers of poultry farming halls, particularly the mentioned barns are exposed to high concentrations endotoxin. With regard to the quantity of endotoxins indicated in Table 5 and Fig.1, and according to the criteria of occupational health committee, the range of endotoxins of the mentioned barns $\left(20-50 \mathrm{ng} / \mathrm{m}^{3}\right)$ may affect the workers with mucous membrane inflammation.

Considering the fact that the permissible ranges are not quite conclusive and the criteria is low in the susceptible population, workers in other poultry barns can also be categorized as risk groups ${ }^{20,21)}$.

In view of the foregoing, the workers of poultry farming are exposed to incidences of systematic symptoms and respiratory diseases due to endotoxin. Since there are a combination of dust, ammonia and endotoxin, they could have significant effects on pulmonary functions. As detailed medical examination of poultry farmers revealed dependence of respiratory and pulmonary disease, cardio vascular and nervous disorders on the labor condition ${ }^{22)}$, development of preventive measures is recommended. On the other hand, the polluted discharge by way of poultry ventilation system into the environment may affect the respiratory health of people living close to these enterprises ${ }^{11)}$. Therefore, the filtration of discharged air becomes a matter of utmost importance.

\section{Acknowledgments}

The authors acknowledge and thank Dr. Fakhrzadegan, head of the Isfahan Veterinary Network Laboratory for her valuable consultation during this research. We would also like to extend our gratitude to Dr. Mahmoudi for his assistance in statistical analysis of the data.

\section{References}

1) Lenhart SW, Morris PD, Akin RE, Otenchock SA, Service WS, Boone WP(1990) Organic dust, endotoxin, and ammonia exposure in the North Carolina Poultry Processing Industry. Appl Occup Environ Hyg 5, 6118.

2) ACGIH (1985) Particle size selective sampling in the workplace, Report of the ACGIH Technical Committee on air sampling procedures. ACGIH, USA.

3) Reynold SJ, Parker D, Vesley D, Janni K, Jilton CMC (1994) Occupational exposure to organic dusts and gases in the turkey growing industry. Appl Occup Environ Hyg 9, 493-502.

4) Crook B (1983) Airborn bacteria, endotoxin and fungi in dust in poultry and swine confinement building. Am Ind Hyg Assoc J 44, 537-41.

5) NIOSH (1984) Manual of analytical methods 3rd ed, U.S. Department of Health \& Human Services, Cincinnati, Ohio.

6) Donham K, Haglind P, Peterson Y, Rylander R, Belin $\mathrm{R}$ (1989) Environmental and health studies of farm workers in Swedish Swine confinement buildings. $\mathrm{Br}$ $\mathrm{J}$ Ind Med 46, 31-7.

7) American Conference of Governmental Industrial Hygienists (ACGIH) (1998) Threshold limit values for chemical substances and physical agents, and biological exposure indices. Cincinnati, Ohio: ACGIH, 17.

8) Lenhart SW, Humphries D (1992) Health hazard evaluation report HETA 91-165-2199, Simmons industries, Inc., Siloam springs, Arkansas. Govt Reports Announcements \& Index (GRA \& I) Issue, 23.

9) Hartung J (1998) Nature and amount of aerial pollutants from livestock building. DTW DTSCH Tierarztl Wochenschr 105, 213-6.

10) Nielsen BH, Breum NO (1995) Exposure to air contaminants in chicken catching. Am Ind Hyg Assoc J 56, 804-8.

11) Atwood RB (1987) A study of the relationship between airborn contaminants and environmental factors in dutch swine confinement building. Am Ind Hyg Assoc J 48, $745-51$

12) Schmidt R, Hoy $S$ (1996) Dust emission from chicken and layer houses. Berl Munch Tierarztl Wochenschr 109, 95-100.

13) Zuskin E, Mustajbegovic J, Schachter EN, Kern J, Rienzi N, Goswami S, Marom Z, Maayani S (1995) Respiratory function in poultry workers and 
pharmacologic characterization of poultry dust extract. Environ Res 70, 11-9.

14) Morris PD, Lenhart SW, Service WS (1991) Respiratory symptoms and pulmonary function in chicken catchers in poultry confinement units. Am J Ind Med 19, 195204.

15) Hagmar L, Schutz A, Hallberg T, Sjoholm A (1990) Health effects of exposure to endotoxins and organic dust in poultry slaughter house workers. Int Arch Occup Environ Health 62, 159-64.

16) Hagmar L, Schutz A, Sjoholm A (1990) Over-shift decrease in lung function in poultry slaughter house workers. Am J Ind Med 17, 77-8.

17) Carvalheiro MF, Peterson $Y$, Rubenowitz E, Rylander $\mathrm{R}$ (1995) Bronchial reactivity and work related syndroms in farmers. Am J Ind Med 27, 65-74.

18) Weaver WD Jr, Meijerho FR (1991) The effect of different levels of relative humidity and air movement on litter condition, ammonia levels, growth and carcass quality for broiler chicken. Poult Sci 70, 746-55.

19) Sanderson WT, Weber A, Echt A (1995) A case reports: epidemic eye and upper respiratory irritation in poultry processing plants. Appl Occup Environ Hyg 10, 43-9.

20) Olenchock SA (1994) Health effects of biological agents: The role of endotoxins. Appl Occup Environ Hyg 9, 62-4.

21) Zejda JE, Barber E, Dosman JA, Olenchock SA, McDuffie HH, Rhodes C, Hurst T (1994) Respiratory health status in swine producers relates to endotoxin exposure in the presence of low dust levels. J Occup Med 36, 49-56.

22) Eglite ME, Kapitonova ME, Karpachevska SI, Farbtukh TA, Khintsenberg TA (1991) Problems of work hygiene and occupational pathology in industrial poultry breeding farms. Gig Tr Prof Zabol Iss-2, 3-6. 